\title{
IMPLEMENTASI KEBIJAKAN SISTEM ZONASI PERSPEKTIF STAKEHOLDER SMP NEGERI 6 METRO
}

\author{
Tri Susiwati ${ }^{1}$, Sudirman Aminin ${ }^{2 *}$, Agus Sutanto ${ }^{3}$ \\ ${ }^{1,2,3}$ Universitas Muhammmadiyah Kota Metro \\ E-mail: $\quad$ rindualmeera@gmail.com ${ }^{1}$ ) \\ sudirman@ummetro.ac.id ${ }^{2}$ * \\ agussutanto@ummetro.ac.id $\left.{ }^{3}\right)$
}

\begin{abstract}
Abstrak
Program pemerataan pendidikan menjadi salah satu usaha pemerintah dalam memajukan Indonesia dibidang pendidikan. Salah satunya kebijakan PPDB Sistem Zonasi, sistem zonasi ini muncul sebagai wujud pemerataan pendidikan dan untuk menghapus brand sekolah unggulan yang telah menyebar di masyarakat. Dengan adanya sistem zonasi diharapkan semua sekolah memiliki kualitas yang sama dan tidak ada lagi sekolah favorit. Dengan adanya kebijakan baru tidak dapat dipungkiri akan menimbulkan banyak permasalahan yang muncul baik dari pihak sekolah dan pihak masyarakat yakni wali murid sebagai pelanggan pendidikan. Tujuan dari Penelitian ini adalah 1) Untuk mengetahui bagaimana implementasi kebijakan sistem zonasi, 2) bagaimana pandangan stakeholder sekolah terkait kebijakan sistem zonasi. Penelitian ini menggunakan pendekatan kualitatif, jenis penelitiannya deskriptif dengan menggunakan rancangan Studi Multisitus. Kemudian teknik pengumpulan datanya diperoleh dari wawancara, dokumentasi, dan observasi penulis secara mendalam. Hasil dari penelitian ini mengungkapkan bahwa empat hal dalam prosess implementasi yang perlu diperhatikan yaitu komunikasi, sumber daya, disposisi, dan struktur birokrasi telah dilakukan dengan baik. Sedangkan SMP Negeri 6 Metro yang menjadi skala prioritas adalah komunikasi. Komunikasi ini merupakan sosialisasi kebijakan kepada kelompok sasaran. Tujuan dari kebijakan sistem zonasi ini harus disosialisasikan secara jelas dan gamblang kepada masyarakat. Salah satu pendukung implementasi kebijakan adalah partisipasi masyarakat. Selain itu juga dapat dilihat dari sudut pandang pelaksana dan aktor diluar badan pemerintahan.
\end{abstract}

Kata kunci: Kebijakan Sistem Zonasi; Perspektif Stakeholder

\begin{abstract}
The education equity program is one of the government's efforts in advancing Indonesia in the field of education. One of them is the PPDB Zoning System policy, this zoning system appears as a form of equal distribution of education and to remove the flagship school brand that has spread in the community. With the zoning system, it is hoped that all schools will have the same quality and there will be no more favorite schools. With the new policy, it is undeniable that it will cause many problems that arise both from the school and the community, namely the guardians of students as education customers. The purposes of this study are 1) To find out how the implementation of the zoning system policy is, 2) what are the views of school stakeholders regarding the zoning system policy. This study uses a qualitative approach, the type of research is descriptive using a multi-site study design. Then the data collection techniques were obtained from interviews, documentation, and in-depth observations of the author. The results of this study reveal that four things in the implementation process that need to be considered, namely communication, resources, disposition, and bureaucratic structure have been carried out well. Meanwhile, for SMP Negeri 6 Metro, the priority scale is communication. This communication is a policy socialization to the target group. The purpose of this zoning system policy must be clearly and clearly communicated to the public. One of the supporters of policy implementation is community participation. In addition, it can also be seen from the point of view of implementers and actors outside government agencies.
\end{abstract}

Keywords: Zoning System Policy keyword1; Stakeholder Perspective 


\section{PENDAHULUAN}

Sistem zonasi merupakan sistem penerimaan peserta didik baru dengan menerapkan zona atau jarak tempat tinggal calon peserta didik dengan sekolah yang dijadikan poin utama dalam penerimaan peserta didik baru. Sistem zonasi merupakan sistem penerimaan peserta didik baru (ppdb) dengan menerapkan zona atau jarak tempat tinggal calon perserta didik dengan sekolah yang dijadikan poin utama dalam penerimaan peserta didik baru.

Kebijakan system zonasi dalam penerimaan peserta didik baru (ppdb) ini sudah mulai diberlakukan sejak tahun 2017. Dalam praktiknya, pada tahun 2017 belum seluruhnya sekolah menerapkan system zonasi dikarenakan masih tahap adaptasi. Tujuan diterapkan system zonasi antara lain untuk menjamin pemerataan akses layanan pendidikan bagi siswa, mendekatkan lingkungan sekolah dengan lingkungan keluarga, menghilangkan eksklusivitas dan deskriminasi di sekolah dengan adanya anggapan sekolah unggulan dan bukan sekolah unggulan. Zonasi atau rayonisasi atau pembagian berdasarkan wilayah sering dilakukan dalam beberapa bidang atas tujuan tertentu dan memperoleh manfaat tertentu. Adapun tujuan zonasi secara umum adalah:

1) Meningkatkan Kualitas : Dengan menggunakan zonasi, hasil pekerjaan bisa lebih berkualitas sesuai potensi kawasannya.

2) Pemerataan : Ada kalanya zonasi dilakukan bertujuan sebagai pemerataan seperti misalnya zonasi pada sistem PPDB agar pendidikan menjadi merata.

3) Memudahkan Pengelolaan zonasi atau rayonisasi dibuat agar memudahkan pengelolaannya menjadi lebih tepat dan efisien.

Penerimaan kebijakan system zonasi dalam ppdb menimbulkan pro dan kontra. Bagi yang pro merasa sepakat dengan kebijakan yang di terapkan oleh pemerintah karena penerapan system zonasi ini merupakan kebijakan pemerintah terhadap seluruh elemen masyarakat untuk pemerataan mutu pendidikan.

\section{METODE PENELITIAN}

Penelitian ini merupakan jenis penelitian deskriptif kualitatif. Moleong (2014:4) mengutip pendapat Bodgan dan Taylor (1975 :5) Metode kualitatif adalah prosedur penelitian yang menghasilkan data deskriptif berupa kata-kata tertulis atau lisan dari orang-orang dan perilaku yang dapat diamati. Pendekatan penelitian yang digunakan dalam penelitian ini adalah studi kasus. Teknik pengambilan informan yang digunakan dalam penelitian ini adalah teknik Purposive Sampling dan Snowball Sampling. Teknik pengumpulan data yang digunakan dalam penelitian ini adalah wawancara, observasi dan analisis dokumen.

Dalam penelitian kualitatif, data diperoleh melalui berbagai sumber dengan meggunakan teknik pengumpulan data yang bermacam-macam, dan dilakukan secara terus menerus sampai datanya jenuh.Dengan pengamatan yang dilakukan secara terus menerus, maka data yang dimiliki memiliki vareasi yang sangat tinggi. Analisis data yang peneliti gunakan adalah analisis data menurut Miles. Kegiatan dalam analisis data ini adalah reduksi data, display data dan kesimpulan.

Untuk menguji kevalidan data digunakan teknik triangulasi data/sumber dan triangulasi metode. Triangulasi data digunakan dalam penelitian oleh peneliti untuk mengumpulkan data dari berbagai sumber, baik dari panitia PPDB Sekolah, kepala sekolah, guru sejarah, orang tua peserta didiksehingga data yang terkumpul tersebut dapat teruji keabsahan dan kebenarannya. Triangulasi metode digunakan peneliti untuk mengumpulkan data dengan metode yang berbeda-beda, seperti wawancara, observasi 
dan analisis dokumen, sehingga diharapkan dengan metode tersebut didapatkan data yang valid dan kesimpulan yang diperoleh memiliki validitas tinggi.

Analisis data dalam penelitian berlangsung bersamaan dengan proses pengumpulan data (Bungin, 2017:144). Analisis kualitatif yang peneliti gunakan adalah teknik deskriptif komparatif dan analisis interaktif yang merupakan proses siklus yang bergerak diantara keempat komponen pokok yaitu pengumpulan data, reduksi atau seleksi data, sajian data dan penarikan kesimpulan.

Penelitian ini diharapkan dapat menemukan sekaligus mendaskripsikan data secara menyeluruh mengenai analisis implementasi system zonasi perspektif stakeholder sekolah.

\section{HASIL DAN PEMBAHASAN}

\section{A. Implementasi Kebijakan Sistem zonasi perspektif stakeholder SMP Negeri 6 Metro}

Proses implementasi kebijakan pendidikan menjadi suatu tahapan penting kebijakan pendidikan. tanpa adanya implementasi, kebijakan hanya akan menjadi sebuah dokumen saja. Dahulu dimana peneliti lebih memusatkan pada proses perumusan sehingga melupakan proses implementasinya. Jika dilihat pada kenyataannya implementasi kebijakan menjadi informasi penting mengenai kebijakan itu sendiri. Implementasi kebijakan menjadi sebuah informasi penting sebagai evaluasi kebijakan tersebut. Karena dengan implementasi kebijakan akan terlihat permasalahan yang muncul serta faktor keberhasilan kebijakan itu sendiri.

Dalam implementasi kebijakan tidak akan serta merta terjadi secara sempurna. Akan terjadi kesenjangan antara rumusan dan pelaksanaannya, yang pada akhirnya akan menimbulkan permasalahan. Permasalahan yang muncul ini akan menjadi kendala dalam proses implementasi kebijakan itu sendiri. Adapun pembahasan hasil dari penelitian implementasi kebijakan system zonasi perspektif stakeholder SMP Negeri 6 Metro adalah sebagai berikut :

Dalam sebuah implementasi kebijakan terdapat beberapa hal yang memang harus diperhatikan. Menurut Edward III terdapat empat hal yang memang harus diperhatikan dalam implementasi kebijakan yaitu Komunikasi, Sumber Daya, Disposisi, dan Struktur Organisasi. Empat hal ini akan mempengaruhi tingkat keberhasilan dan kegagalan implementasi suatu kebijakan yaitu:

1. Komunikasi

Komunikasi menjadi suatu hal yang penting karena kebijakan akan berjalan lancar dengan adanya komunikasi yang baik antara implementator dan sasaran kebijakan. Hal ini dimaksudkan agar tujuan dari kebijakan itu sendiri dapat tercapai dan tepat sasaran. Komunikasi disalurkan kepada kelompok sasaran agar kelompok sasaran memahami tujuan dari kebijakan itu sendiri.

Untuk sosialisasi kebijakan sistem zonasi sendiri dari dinas pendidikan kepada kepala sekolah dilakukan melalui MKKS yang dilakukan oleh dinas pendidikan kepada seluruh kepala sekolah di wilayah kota Malang. Sedangkan sosialisasi dari sekolah yaitu SMP Negeri 6 Metro kepada masyarakat yaitu wali murid dilakukan dengan berbagai metode seperti:

a. Pengumuman secara online di web dan berita

b. Penempelan pengumuman di papan pengumuman

c. Pembukaan ruang informasi bagi masyarakat

Selain proses sosialisasi dalam komunikasi suatu ebijakan juga berkaitan dengan kejelasan dan konsistensi dalam penyampaian instruksi. Dalam hal ini instruksi kepala 
sekolah sebagai penanggung jawab sudah cukup jelas dan konsisten. Kejelasan dan konsistensi dalam komunikasi kebijakan sangat diperlukan demi tercapainya tujuan kebijakan. Sebagaimana yang disebutkan Widodo (2017) menyatakan bahwa:

Dimensi transformasi menghendaki agar kebijakan publik dapats ditransformasikan kepada para pelaksana, kelompok sasaran, dan pihak lain yang terkait dengan kebijakan. Dimensi kejelasan (clarity) menghendaki agar kebijakan yang ditransmisikan kepada para pelaksana, target grup, dan pihak lain yang berkepentingan langsungmaupun tidak langsung terhadap kebijakan dapat diterima dengan jelas sehingga diantara mereka mengetahui apa yang menjadi maksud, tujuan, dan sasaran serta substansi dari kebijakan publik tersebut. Jika tidak jelas, mereka tidak akan tahu apa yang seharusnya dipersiapkan dan dilaksanakan agar tujuan kebijakan dapat dicapai secara efektif dan efisien.

\section{Sumber Daya}

Dalam sebuah implementasi kebijakan sumber daya menjadi suatu hal yang sangat penting. Tanpa adanya sumber daya maka kebijakaan tidak akan berjalan lancar. Menurut Edward III sebagaimana yang dikutip Joko Widodo bahwa "Bagaimanapun jelas dan konsistennya ketentuan-ketentuan atau aturan-aturan tersebut, jika para pelaksana kebijakan yang bertanggung jawab untuk melaksanakan kebijakan kurang mempunyai sumber-sumber daya untuk melakukan pekerjaan secara efektif, maka implementasi kebijakan tersebut tidak akan efektif.

Dalam proses pelaksanaan kebijakan sistem zonasi ini SMP Negeri 6 Metro mempersiapkan tenaga pendidik mereka dengan mengadakan pelatihan dan workshop untuk meningkatkan kompetensi mengajar guru. Selain itu sekolah menyediakan laboratorium, jaringan internet serta perpustakaan untuk membantu siswa dalam belajar serta mencari bahan pembelajaran.

Hal ini mengingat heterogenitas siswa hasil dari sistem zonasi. Untuk itu perlu upaya lebih dalam membantu siswa yang memiliki kemampuan dibawah KKM. Perbaikan kualitas layanan sumber daya dilakukan untuk mengatasi permasalahan yang ada karena adanya kebijakan sistem zonasi.

3. Disposisi

Disposisi ini yang menyangkut kesediaan dan kimitmen penyelenggara untuk melaksanakan kebijakan. Edward III menegaskan sebagaimana yang dikutip Joko Widodo bahwa "Keberhasilan implementasi kebijakan bukan hanya ditentukan oleh sejauh mana para pelaku kebijakan (implementators) mengetahui apa yang harus dilakukan dan mampu melakukannya, tetapi juga ditentukan oleh kemampuan para pelaku kebijakan tadi memiliki disposisi yang kuat terhadap kebijakan yang sedang diimplementasikan.

Dalam hal ini SMP Negeri 6 Metro mendukung adanya sistem zonasi ini. Hal ini juga dikarenakan tujuan dari kebijakan ini untuk pemerataan, sehingga pelaksana mendukung untuk terlaksananya kebijakan ini. Selain itu dengan adanya sistem zonasi input dari masing-masing sekolah menjadi heterogen. Untuk itu sekolah berusaha membangun sikap kreatifitas guru dalam mengajar dengan mengadakan workshop, serta menumbuhkan motivasi guru dalam mengajar. Karena untuk menghadapi heterogenitas siswa ini diperlukannya motivasi dan kreativitas guru untuk membantu siswa agar terpacu untuk berprestasi.

Jadi, motivasi ini tidak hanya diberikan kepada siswa saja. Namun, kepada guru sebagai pendidik juga perlu adanya pacuan semangat. Suatu kebijakan ini akan dikatan gagal ketika sebuah kebijakan tidak terimplementasikan. Sebagaimana yang dijelaskan 
Wahab (2012) Tidak terimplementasikan ini mengandung arti bahwa suatu kebijakan dilaksanakan sesuai rencana, mungkin karena pihak-pihak yang terlibat di dalam pelaksanaannya tidak mau bekerjasama, atau mereka telah bekerja secara tidak efisien , bekerja setengah hati, atau karena mereka tidak sepenuhnya menguasai permasalahan, atau kemungkinan permasalahan yang digarap di luar jangkauan kekuasaan, sehingga betapapun gigih usaha mereka, hambatan-hambatan yang ada tidak sanggup mereka tanggulangi. Akibatnya, implementasi yang efektif sukar untuk dipenuhi.

\section{Struktur Birokrasi}

Keberhasilan implementasi kebijakan yang kompleks, perlu adanya kerjasama yang baik dari banyak orang. Oleh karena itu, fragmentasi organisasi dapat mempengaruhi koordinasi yang diperlukan untuk implementasi suatu kebijakan yang kompleks dan dapat menimbulkan pemborosan sumber daya yang langka. Adanya perubahan yang tidak diinginkan akan menimbulkan kegaduhan, kebingungan yang mengarah pada pelaksanaan kebijakan yang menyimpang dari tujuan semula yang telah ditetapkan sebelumnya. Demikian juga dengan tidak jelasnya Standart Operational Procedure (SOP), baik menyangkut mekanisme, sistem dan prosedur pelaksanaan kebijakan, pembagian tugas pokok, fungsi, kewenangan, dan tanggung jawab diantara para pelaku, dan tidak harmonisnya hubungan diantara organisasi pelaksana satu dengan lainnya, ikut pula menentukan gagalnya pelaksanaan suatu kebijakan.

Kepala SMP Negeri 6 Metro membuat persiapan perencanaan terlebuh dahulu sebelum pelaksanaan PPDB, dengan di bantu oleh waka kurikulum sekolah, yaitu dengan persiapan pembentukan panitia PPDB, kemudian di sosialisikan dalam rapat dewan guru dan staf tata usaha. Kemudian panitia akan menyusun tim yang terlibat dalam proses pelaksanaan PPDB.

Pada tahap perencanaan ini kepala sekolah melaksanakan pengecekan tim dan semua teknis yang berhubungan dengan PPDB. 1) panitia yang bertugas, 2) perlengkapan teknis seperti komputer atau laptop, 3) jaringan internet. Apabila belum lengkap atau ada kekurangan maka akan segera di tindak lanjuti.

\section{B. Pandangan Stakeholder Sekolah Terhadap Implementasi Sistem Zonasi di SMP Negeri 6 Metro.}

Stakeholders Internal adalah : Orang-orang yang memiliki kepentingan dan tuntutan terhadap sumber daya perusahaan serta berada di dalam organisasi perusahaan. Salah satu faktor pendukung implementasi kebijakan adalah partisipasi masyarakat. Menurut Huntington (dalam Abidin, 2016).

Partisipasi merupakan ciri khas dari masyarakat modern. Di negara- negara yang belum modern, sebagian besar masyarakatnya belum merasa penting untuk berpartisipasi dalam kebijakan pemerintah. Mereka belum merasa bahwa kebijakan pemerintah mempunyai pengaruh terhadap kehidupannya, apalagi untuk berfikir bahwa mereka mempunyai hak dan mampu mempengaruhi kebijakan pemerintah itu untuk kepentingannya. Bagi mereka, urusan pemerintah adalah urusan para elite, yakni mereka yang berada di luar dunia kehidupan mereka.

Partisipasi ini dapat berbentuk dukungan atau persetujuan, dapat pula berbentuk penolakan atau pertentangan. Kedua bentuk partisipasi ini dalam manajemen publik sama pentingnya karena sama-sama memberi pengaruh terhadap kebijakan publik. Karena keduanya merupakan masukan yang diperlukan dalam proses perumusan dan implementasi kebijakan. Partisipasi ini dikenal dalam dua bentuk yaitu pertama, murni karena muncul spontan dari rakyat. Kedua, mobilisasi, yaitu partisipasi yang 
diorganisasi oleh pihak

tertentu.

\section{Pandangan Stakeholder EksternalTerhadap Implementasi Sistem Zonasi di SMP Negeri 6 Metro.}

Stakeholders Eksternal adalah orang-orang atau pihak-pihak yang bukan dari perusahaan atau di luar dari perusahaan tetapi memiliki kepentingan terhadap perusahaan dan atau dipengaruhi oleh keputusan serta tindakan yang dilakukan oleh perusahaan. (Solihin, 2009:51). Yang termasuk kategori stakeholders eksternal adalah pelanggan, pemasok, pemerintah, kreditor, serikat pekerja, komunitas lokal dan masyarakat umum. Sedangkan dalam lingkungan pendidikan yang menjadi stakeholder eksternal adalah pemerintah dan masyarakat. Masyarakat sebagai pelanggan pendidikan juga diperlukan suatu wawasan dan pengetahuan untuk berbaikan, karena pada dasarnya kebijakan ini juga dibuat untuk kepentingan masyarakat. Saran yang diberikan masyarakat adalah bahwa sistem zonasi dilakukan dengan standar nilai yang sesuai dengan standar nilai sekolah.

Selain itu perlunya evaluasi dan tinjauan ulang wilayah yang menjadi zonasi setiap sekolah. Hal ini dikarenakan tidak semua wilayah memiliki kelompok usia sekolah yang sama dan tidak semua kecamatan memiliki sekolah negeri. Dalam hal ini yang menjadi stakeholder eksternal pendidikan adalah pemerintah dan masyarakat. Menurut Harahap (2014) Legitimasi masyarakat merupakan faktor strategis bagi perusahaan dalam rangka mengembangkan perusahaan ke depan. Hal itu dapat dijadikan sebagai wahana untuk mengonstruksi strategi perusahaan, terutama terkait dengan upaya memposisikan diri di tengah masyarakat. Teori legitimasi mengandung pengertian bahwa aktivitas berupa tanggung jawab sosial perusahaan merupakan suatu usaha yang berkenaan dengan tekanan dari lingkungan sekitar, misalnya tekanan politik, sosial maupun ekonomi. Menurut Ghozali dan Chariri (2007), sebagai dasar dari teori legistimasi adalah adanya kontrak sosial yang terjadi antara perusahaan dan masyarakat dimana perusahaan beroperasi dan menggunakan sumber ekonomi. Selain itu, dijelaskan bahwa dalam masyarakat yang dinamis, tidak ada sumber kekuatan institusional dan kebutuhan terhadap pelayanan yang bersifat permanen. Oleh karena itu, suatu institusi harus lolos uji legistimasi dan relevansi dengan cara menunjukkan bahwa masyarakat memerlukan jasa tenaga pendidik.

Sistem zonasi dimaksudkan untuk mempercepat pemerataan kualitas pendidikan di Indonesia. Sistem zonasi diharapkan dapat menghilangkan Kasta dalam sistem pendidikan di Indonesia. Setiap elemen masyarakat mempunyai kesempatan yang sama untuk mendapatkan pendidikan yang berkualitas. Sistem zonasi PPDB diharapkan dapat menghilangkan dikotomi sekolah unggulan/favorit dan nonunggulan/sekolah pinggiran.

SMP Negeri 6 Metro sebagai lembaga pendidikan yang menjalankan regulasi dari pemerintah sudah melaksanakan PPDB dengan sistem zonasi sesuai dengan Petunjuk Teknis (Juknis) dan Peraturan yang ditetapkan oleh pemerintah. Dalam menyusun Rombongan Belajar (Rombel) semua sekolah sudah menerapkan Juknis dan peraturan yang berlaku yaitu penyusunan Rombel secara heterogen. Peserta didik yang berkemampuan akademik tinggi di tempatkan secara merata di semua kelas sehingga diharapkan dapat memberi tutor sebaya untuk peserta didik lain yang berkemampuan akademik sedang/kurang. SMP Negeri 6 Metrosudah tidak lagi mempunyai kelas eksklusif/ unggulan. Sekolah sudah berlaku adil dalam pengelolaan peserta didik baru untuk mempertahankan mutu pendidikan. Dalam memanajeman peserta didik baru 
setiap sekolah mempunyai peraturan yang tegas untuk mendisiplinkan setiap peserta didik. Peserta didik memiliki kewajiban dan hak yang sama yaitu memperoleh pelayanan pendidikan yang adil.

\section{KESIMPULAN}

Dari penelitian yang dilakukan maka disimpulkan pemerataan sistem zonasi pada implementasi sistem zonasi pada SMP Negeri 6 Metro masih ditemukan kesulitan kepala sekolah dalam pemerataan PPDB sehingga perlu adanya perenvanaan pelaksanaan dan evaluasi yang dilakukan serta disusun sedemikian rupa agar mendapatkan hasil maksimal kedepan. Pelaksanaan kebijakan sistem zonasi yang di lakukan oleh kepala SMP Negeri 6 Metro adalah dalam bentuk kepala sekolah memberikan tanggapan kepada wali murid dengan melakukan penjelasan atau klarifikasi tentang penerimaan sistem zonasi. Kepala sekolah juga menerima kritik dan tanggapan dari para wali murid. Dalam setiap permasalahan perlu adanya solusi untuk memecahkan permasalahan tersebut. Tindakan yang dilakukan untuk mengatasi masalah tersebut diantaranya menyiapkan SDM serta penyusunan program sekolah.

\section{DAFTAR PUSTAKA}

Abidin, Said Zainal. (2016). Kebijakan Publik Edisi 3. Jakarta: Salemba Humanika.

Aullia Rahmawati dan Muflihatin. (2018). Komunikasi Dalam Implementasi Kebijakan Penerimaan Peserta Didik Baru (PPDB) Zonasi Di Sekolah Menengah Pertama (SMP) Kabupaten Kediri. Skripsi. Universitas Erlangga.

Burhan Bunging. (2007). Penelitian Kualitatif. Jakarta: Kencana.

Haryanti, Amelia., Abi Robian, Dindin. (2020). Implementasi Kebijakan Sistem Zonasi pada Penerimaan Peserta Didik Baru Tahun 2020. Prosiding Senantias. Vol 1 No 1 Hal 61-70.

Herdiansyah. H. (2010). Metode Penelitian Kualitatif: Jakarta: Salemba Humanika.

Moleong, Lexy.J. (2005). Metode Penelitian Kualitatif. Bandung: Rosdakarya.

Permendikbud No. 44 Tahun 2019. Tata Cara Penerimaan Peserta Didik Baru (PPDB).

Purwanti, dkk. (2019). Implementasi Kebijakan Penerimaan Peserta Didik Baru berdasarkan Sistem Zonasi di Kota Bandung. Jurnal Governansi p-ISSN 2442-3971 e-ISSN 2549-7138, Volume 5 Nomor 1, April 2019

Rahardjo, Mudjia. (2010). Pemikiran Kebijakan Pendidikan Kontemporer. Malang: UIN Maliki Press.

Sugiyono. (2012). Metode Penelitian manajemen. Bandung: Alfabeta.

Sukirman. (2009). Persepsi Stakeholder Sekolah Terhadap Tingkat Kepentingan Penyajian Laporan Keuangan. Jurnal Dinamika Akuntasi. Vol 2.(2) September, 2009. Hal 86-98. 
Syafitri, Eni., Agus Mahfud Fauzi. (2021). Implementasi Kebijakan Sistem Zonasi dalam Pemerataan Pendidikan di SMAN 1 Kamal. Jurnal Equalibrium. Vol 18 No 1 Hal 33-40.

Wahab, Solichin Abdul. (2012). Analisis Kebijakan: Dari Formulasi ke Penyusunan model-model Implementasi Kebijakan Publik. Jakarta: Bumi Aksara.

Tilaar, H.A.R dan Riant Nugroho. (2009). Kebijakan Pendidikan: Pengantar Untuk Memahami Kebijakan Pendidikan dan Kebijakan Pendidikan sebagai Kebijakan Publik. Yogyakarta: Pustaka Pelajar.

Ula, D.M \& Lestari, I. (2019). Imbas Sistem Zonasi bagi Sekolah Favorit dan Masyarakat. Prosiding Seminar Nasional Pendidikan Dan Pembelajaran 2019 Reorientasi Profesionalisme Pendidik Dalam Menghadapi Tantangan Revolusi Industri 4.0.hal 195-201.

Widodo, Joko. (2017). Analisis Kebijakan Publik: Konsep dan Aplikasi Analisis Proses Kebijakan Publik. Malang: Media Nusa Creative. 